\title{
8. TEXTURAL AND MICROSTRUCTURAL EVIDENCE FOR SEDIMENT DIAGENESIS IN THE VICINITY OF THE CHILE TRIPLE JUNCTION ${ }^{1}$
}

\author{
N. Lindsley-Griffin, ${ }^{2}$ D.J. Prior, ${ }^{3}$ J.R. Griffin,${ }^{2}$ M.K. Tozer, ${ }^{2}$ and E.L. Rochford ${ }^{3}$
}

\begin{abstract}
Petrographic analysis of textures and microstructures in muds and mudstones from the Chile Triple Junction reveals that formation of framboidal pyrite begins in the top few meters below sea floor (mbsf), and continues during and after the formation of such features as vein structures, faults, and microfaults. Pyrite formation is strongly influenced by primary porosity, as shown by the many microfossils filled by pyrite and by major concentrations of pyrite localized within coarser grain sizes. Some microfossil shells are coated and outlined by pyrite, and many calcareous microfossils are partially dolomitized. Glauconite and phosphate occur as clasts in sand- and silt-sized lithologies. Rare phosphatic concretions form in place within organic-rich muds. Cataclastic fabrics form along some microfaults, but other planar structures exhibit little or no deformation. Microfaults, fractures, and vein structures play an important part in the transport of fluids during diagenesis and lithification.
\end{abstract}

\section{INTRODUCTION}

The purpose of this research is to examine the textural evidence for diagenesis and early deformation exhibited by samples from the vicinity of the Chile Triple Junction. We are testing the hypothesis that both diagenesis and deformation begin very early in marine sediments and are affected by other processes associated with the collision and subduction of an active ridge segment at the Chile Triple Junction. The predicted elevated thermal gradients, fluids venting from the active ridge, and hydrothermal alteration should enhance diagenesis. Sites 859,860 , and 861 are located along a transect north of the triple junction (Fig. 1), from deeper water to shallower water, respectively. Site 863 , at the base of the trench slope, is located at the point where the Chile Ridge is being subducted. Site 862 is located at the crest of the Taitao Ridge, a probable offshore analog to the Taitao ophiolite on the Taitao Peninsula (Forsythe and Prior, 1992; Kurnosov et al., this volume). The oceanic basement at Site 862 is covered with a thin blanket of sediments and sedimentary rocks, from which 9 samples were collected for this study.

\section{METHODS}

\section{Sample Collection}

Approximately 200 samples of characteristic lithologies were collected during Leg 141. One or two samples were collected from every core in the first 50 meters below seafloor (mbsf) where recovery permitted; at greater depths one or two samples were collected from every second or third core as recovery permitted. Hard lithologies were sawed into thin-section blanks aboard ship; these survive transit to the onshore laboratory best if packed in plastic pop-top vials before being sealed in plastic sample bags. Friable or fractured semi-lithified samples also survive transit best in plastic vials.

Proper handling of the soft sediment samples is critical to preserve primary textures and microstructures. The most effective sampling technique is to press an oriented plastic sample box gently into the

\footnotetext{
'Lewis, S.D., Behrmann. J.H., Musgrave, R.J., and Cande, S.C. (Eds.), 1995. Proc. ODP, Sci. Results, 141: College Station, TX (Ocean Drilling Program).

${ }^{2}$ Department of Geology, 214 Bessey Hall, University of Nebraska, Lincoln, NE 68588-0340, U.S.A.

${ }^{3}$ Department of Earth Sciences, Liverpool University, Liverpool L69 3BX, United Kingdom.
}

mud until its bottom is flush with the cut face of the core, then use a spatula to lift both the box and the encased sample out. Most samples used for this study were collected in the $6 \mathrm{~cm}^{3}$ boxes used for paleomagnetic sampling; selected larger structures were collected in $4.5 \times$ $1.5 \mathrm{~cm}, 24 \mathrm{~cm}^{3}$ plastic boxes. After placing the lid on the box, it is sealed in a plastic sample bag and the sealed bag is placed in a second plastic bag with a small piece (1 to $2 \mathrm{~cm}$ square) of moistened sponge and sealed. If samples are refrigerated aboard ship and in the onshore lab, they will remain fresh for many months. It is not necessary to ship the samples in a refrigerated state.

It is imperative that pelitic samples not be frozen. Eight samples were frozen by mistake aboard ship; six of these exhibit anomalous structures similar to desiccation cracks, oriented concentrically about the margins of the sample. In clays and fine silts, freezing disruption is so severe as to preclude their use in textural studies, although they may be used to determine composition. The coarse silts and fine sands are less disrupted by freezing and may be of some use in textural studies.

\section{Sample Preparation}

Some hard samples of sandstone and silty mudstone can be made into thin sections directly; if fractured or friable they can be impregnated first with a standard epoxy. The samples of soft muds are more difficult to prepare, requiring a low viscosity epoxy and a complex preparation sequence as described by Swartz and Lindsley-Griffin (1990). The procedure requires soaking the sample in acetone or alcohol to replace the pore water; if the sample dries out the delicate textures and microstructures will be destroyed by numerous desiccation cracks. The acetone-treated sample is soaked in the low viscosity epoxy for several days, then hardened in an oven at very low temperatures. Although the low-viscosity epoxy is necessary to penetrate the relatively impermeable clays and fine silts, a major drawback is that it never hardens to the consistency of rock. Automated thin-section equipment is too rough on the samples and destroys them by extensive plucking. The best way to produce a thin section of the impregnated soft mud is by hand grinding the samples one at a time. The thin section must be watched closely for signs of plucking, and grinding must be halted as soon as the sample is thin enough to pass light if it begins to disintegrate. Although some finished thin sections exhibit a few isolated desiccation cracks, the fragments between such cracks retain undisturbed primary textures. Thin sections were examined by standard petrographic techniques; most thin sections were stained for calcite with Alizarin Red-S. 
Table 1. Occurrences of authigenic minerals other than framboidal pyrite in Leg 141 samples.

\begin{tabular}{|c|c|c|c|c|c|c|c|}
\hline $\begin{array}{l}\text { Core, section. } \\
\text { interval (cm) }\end{array}$ & $\begin{array}{l}\text { Depth } \\
\text { (mbsf) }\end{array}$ & I & 2 & 3 & 4 & 5 & 6 \\
\hline \multicolumn{8}{|l|}{$141-859 \mathrm{~A}-$} \\
\hline $2 \mathrm{H}-3,38-40$ & 4.58 & - & - & - & - & - & 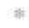 \\
\hline $3 \mathrm{H}-3,76-78$ & 14.46 & a & - & - & - & - & - \\
\hline $3 \mathrm{H}-4,95-97$ & 16.15 & - & $\Rightarrow$ & - & - & - & - \\
\hline $6 \times-2.55-57$ & 36.75 & - & - & - & - & - & $*$ \\
\hline $8 \mathrm{X}-\mathrm{CC} \cdot 11-13$ & 50.61 & - & - & * & - & - & - \\
\hline \multicolumn{8}{|l|}{$141-859 \mathrm{~B}-$} \\
\hline $3 R-7.14-16$ & 78.94 & - & \# & - & - & - & - \\
\hline $\begin{array}{l}141-859 \mathrm{~A}- \\
13 \mathrm{X}-\mathrm{CC} 2 \mathrm{I}-23\end{array}$ & & & & & & & \\
\hline $\begin{array}{l}13 X-C C .21-23 \\
16 X-C C .30-32\end{array}$ & $\begin{array}{r}79.79 \\
100.85\end{array}$ & - & $\overline{-}$ & * & $\overline{-}$ & $\overline{-}$ & - \\
\hline \multicolumn{8}{|l|}{$141-859 \mathrm{~B}-$} \\
\hline $14 R-4,48-50$ & 240.28 & - & * & - & - & - & - \\
\hline $21 \mathrm{R}-2,43-45$ & 304.73 & - & - & - & - & $*$ & - \\
\hline \multicolumn{8}{|l|}{$141-860 B-$} \\
\hline $3 \mathrm{H}-7.1-6$ & 19.91 & - & - & - & - & * & - \\
\hline $4 \mathrm{H}-2,41-43$ & 22.31 & - & * & - & - & - & - \\
\hline $12 \times-4,103-104$ & 93,23 & - & - & - & - & - & 非 \\
\hline $19 \times-4,11-13$ & 141.71 & - & + & - & - & - & at \\
\hline $19 \times-4.71-73$ & 142.31 & - & $\Rightarrow$ & - & - & - & - \\
\hline $25 X-1.98-100$ & 195.08 & $\Rightarrow$ & - & - & - & - & - \\
\hline $58 X-1.91-93$ & 493.71 & - & - & - & $=$ & - & - \\
\hline $67 X-1.63-67$ & 579.83 & - & - & * & - & - & - \\
\hline $67 X-3,22-24$ & 582.42 & - & - & t & - & - & - \\
\hline \multicolumn{8}{|l|}{$141-861 \mathrm{~A}-$} \\
\hline $1 \mathrm{H}-4,18-20$ & 4.68 & - & - & $\Rightarrow$ & 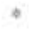 & - & - \\
\hline \multicolumn{8}{|l|}{$141-861 \mathrm{C}$} \\
\hline $2 \mathrm{H}-5,42-45$ & 9.42 & - & क & - & - & - & - \\
\hline $3 \mathrm{H}-3,128-130$ & 16.78 & - & - & s & - & - & - \\
\hline $16 \times-3.99-101$ & 132.89 & - & - & $\Rightarrow$ & $\Rightarrow$ & - & - \\
\hline $18 X-2.28-30$ & 150.28 & - & - & $\%$ & क & - & - \\
\hline $18 \times-4,85-87$ & 153.85 & - & - & - & - & * & - \\
\hline $22 \times-2.31-33$ & 181.71 & - & - & - & - & - & $\&$ \\
\hline $22 \times-4,17-19$ & 184.57 & - & * & - & - & - & - \\
\hline $36 x-1,131-133$ & 296.91 & - & $*$ & - & - & - & - \\
\hline $41 \times-3.67-69$ & 347.07 & - & - & - & - & - & a \\
\hline $41 X-3.86-88$ & 347.26 & - & - & - & - & - & $=$ \\
\hline \multicolumn{8}{|l|}{$141-863 \mathrm{~A}$} \\
\hline IH $-4,66-72$ & 5.16 & $*$ & - & - & - & _ & - \\
\hline $4 \mathrm{H}-2,80-82$ & 29.90 & - & * & - & - & - & - \\
\hline $21 X-1.40-42$ & 191.70 & - & $\approx$ & - & - & _ & _ \\
\hline $4 X-2,142-144$ & 328.82 & * & - & - & - & - & - \\
\hline $8 \mathrm{~N}-1.28-33$ & 357.68 & - & - & - & - & - & - \\
\hline \multicolumn{8}{|l|}{$14 \mid-863 \mathrm{~B}$} \\
\hline $14 \mathrm{R}-1.100-112$ & 406.50 & * & a & - & - & - & - \\
\hline 2 IR-2.91-95 & 474.99 & _- & - & - & 4 & is & - \\
\hline $23 R-1.124-128$ & 493.64 & - & \$ & - & - & - & - \\
\hline $41 \mathrm{R}-2,119-126$ & 668.19 & - & - & - & - & - & * \\
\hline $42 \mathrm{R}-1,70-76$ & 675.90 & - & - & - & - & - & $*$ \\
\hline $49 R-1,53-56$ & 733.73 & - & - & - & - & - & $\Rightarrow$ \\
\hline
\end{tabular}

Notes: * = observed, $-=$ not observed: 1 = phosphatic concretions growing in place: 2 = phosphatic muds: $3=$ phosphatic fecal pellets: $4=$ dolomitized or partially dolomitized calcareous shells and tests: $5=$ calcite cement: $6=$ siliceous microfossils preserved. suggesting above Opal-A to Opal-CT boundary.

\section{TEXTURAL OBSERVATIONS OF AUTHIGENIC MINERALS}

Authigenic minerals observed in the Leg 141 samples include zeolites, glauconite, phosphate concretions, dolomite, possible Opal-CT, quartz, and framboidal pyrite. Although zeolites are present (Behrmann, Lewis, Musgrave, et al., 1992; Marsaglia et al., this volume) they are too small to readily identify in these thin sections. Glauconite occurs in trace amounts as clasts in some of the silt and sand layers, but clear examples of in-place authigenic glauconite have not been observed.

\section{Phosphate and Associated Material}

Phosphate concretions appear to be rare and poorly developed in samples from the Chile Triple Junction, in contrast to sediments from areas more strongly affected by coastal upwelling (Garrison and
Kastner, 1990; Lindsley-Griffin et al., 1990; Griffin and LindsleyGriffin, 1992). In these samples, phosphate occurs in the form of apatite or fluorapatite fish-bone fragments, hard crystalline nodules, soft friable concretions, phosphatic mud, and phosphatic fecal pellets.

Fragments of apatite or fluorapatite fish bones are ubiquitous in trace amounts and are observed in every thin section. They are typically less than $100 \mu \mathrm{m}$ long, but larger fragments are present (PI. 1, Fig. 1). The hard crystalline phosphate nodules (PI. 1, Fig. 2) are typically brightly colored in shades of yellowish orange and reddish orange, with sharp well-defined boundaries and relatively high relief. They probably are analogous to the D-phosphates of Garrison and Kastner (1990) and may represent reworked clasts.

The soft friable phosphates (Pl. 1, Fig. 3), analogous to the carbonate fluorapatite F-phosphates of Garrison and Kastner (1990), are translucent clouds of dark reddish-orange material. They have fuzzy, indistinct boundaries and may wrap around and enclose silt and sand grains, suggesting that they formed in place. Phosphatic mud consists of clay grains coated or cemented by apatitic phosphate; it exhibits the typical light to dark gray birefringence of apatite, appearing dark gray in cross-polarized light, a deep reddish orange in plane light. Pyrite framboids are more abundant within the phosphatic muds, as is a yellowish brown material that may be organic matter (kerogen?). Some fecal pellets appear to be phosphatic as well (Pl. 1, Fig. 4). Locations of samples with authigenic phosphatic concretions that formed in place are indicated in Table 1, as are samples containing phosphatic muds and phosphatic fecal pellets.

\section{Dolomite and Calcite}

Many calcareous microfossil tests are partially dolomitized, as evidenced by their being only partially stained by Alizarin Red-S. The example in Plate 1, Figure 5, shows a foraminifer filled with pyrite, whose test is covered by an outer layer of dolomite (white border). The inner layer exhibits calcite stain, seen in the photomicrograph as a gray textured area, but borings within that part of the test also appear to be filled with white dolomite. Figure 6 (Pl. 1) shows another foraminifer with an outer layer of dolomite and an inner layer of calcite, but the test is partially filled and coated with framboidal pyrite. Table 1 indicates samples in which dolomitized tests and shells have been observed.

Carbonate veins, burrow fillings, and cement were recognized aboard ship, especially in cores from Site 863. Samples in which calcite cement has been observed are indicated in Table 1.

\section{Silica}

Although the Opal-A/Opal-CT and Opal-CT/quartz boundaries were not determined aboard ship, some textural evidence relates indirectly to the location of these boundaries as well as to silica diagenesis. Shipboard paleontological studies revealed an overall lack of siliceous microfossils, with diatoms disappearing altogether from core catcher samples at depths of 260-328 mbsf at Sites $859-861$ and 863 (Behrmann, Lewis, Musgrave, et al., 1992). Siliceous microfossils such as diatoms (Pl. 1, Fig. 7) are observed in thin sections of some samples as indicated in Table 1. Although the preservation of delicate microfossil structures is unlikely below the Opal-A/CT boundary, partially dissolved siliceous microfossils are observed to depths of 347.26 mbsf in samples from Site 861 (Table 1).

Shipboard XRD analyses found "an unidentified amorphous phase" in every sample (Behrmann, Lewis, Musgrave, et al., 1992). In almost every thin section, fuzzy clouds of an unidentified isotropic material are irregularly dispersed in the finer grain sizes (clay and fine silt) - probably the unidentified amorphous phase. The material is noncrystalline or cryptocrystalline, translucent in plane light (thus not opaque), and isotropic in cross-polarized light. It surrounds clay and silt particles without replacing them. This substance may be remobilized silica, derived from devitrification and dissolution of volcanic glass and glassy lithic fragments, including obsidian, dacitic pumice, 


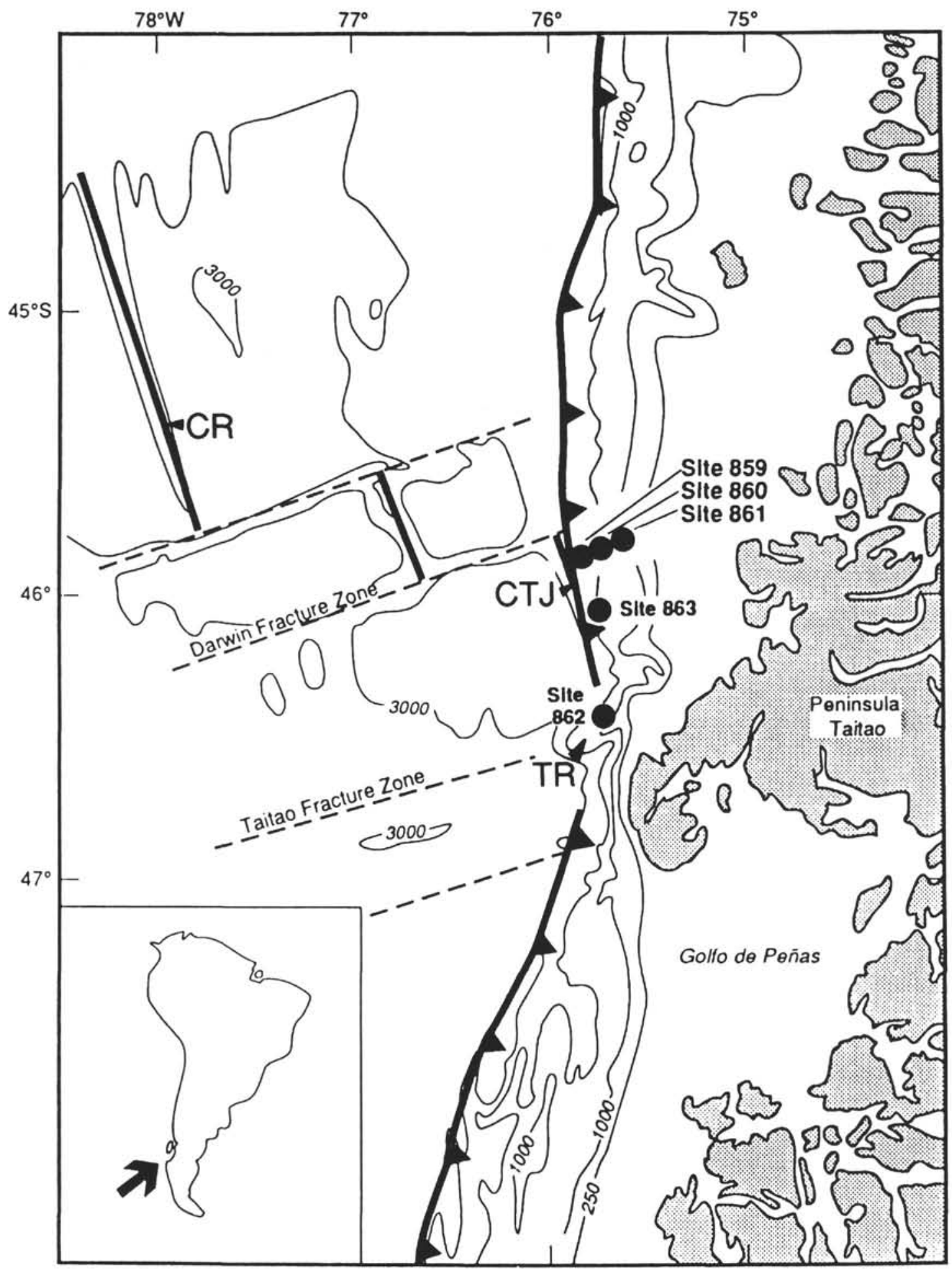

Figure 1. Map of Chile Triple Junction showing geographic and tectonic features relative to locations of Sites 859, 860, 861, 862, and 863 (after Fig. 1, Behrmann, Lewis, Musgrave, et al., 1992). Bathymetry in meters. Toothed line indicates convergent margin (Chile Trench). Bold straight lines indicate divergent margin (Chile Ridge).

and glassy microlitic fragments. Figure 8, Plate 1, shows a clast at 9.45 mbsf that consists of feldspar laths surrounded by volcanic glass; the glass is just beginning to devitrify, as shown by subisotropic areas within it. At $426.86 \mathrm{mbsf}$, the volcanic clast in Figure 9, Plate 1, has undergone almost complete dissolution to form an isotropic cloud of silica that nearly conceals the phenocrysts within it. Another possible source of amorphous silica is the dissolution of diatoms and other siliceous microfossils, or from the Opal-A to Opal-CT conversion of biogenic silica.

\section{Iron Sulfides}

Iron sulfides are the dominant authigenic minerals in Chile Triple Junction samples. Shipboard analyses showed that iron sulfides are 
present as pyrite and as greigite $\left(\mathrm{Fe}_{3} \mathrm{~S}_{4}\right)$ (Behrmann, Lewis, Musgrave, et al., 1992). For the sake of brevity, we use "pyrite" to refer to all forms of iron sulfide observed in the samples studied.

Pyrite is ubiquitous, appearing in every sample, and locally it is present in accessory amounts (Table 2). Pyrite occurs even in the shallowest samples collected in each hole, namely at depths of $4.39,4.58$, $4.82,5.05$, and 6.33 mbsf (respectively, Samples 141-862A-1H-3, $139-141 \mathrm{~cm},-859 \mathrm{~A}-2 \mathrm{H}-3,38-40 \mathrm{~cm},-863 \mathrm{~A}-1 \mathrm{H}-4,32-38 \mathrm{~cm},-860 \mathrm{~B}-$ $2 \mathrm{H}-3,65-76 \mathrm{~cm}$, and $-861 \mathrm{~B}-1 \mathrm{H}-5,33-35 \mathrm{~cm}$ ). It typically consists of clusters of tiny raspberry-shaped framboids either disseminated throughout the sediment or clustered into concretions ranging from a few tens of microns to more than $1 \mathrm{~cm}$ in diameter (Pl. 2, Figs. 1 and 2 ). Evidence that the pyrite concretions formed in place includes irregular margins with projecting framboid clusters, interstitial fillings of pyrite (Pl. 2, Fig. 3), replacement of primary bedding (Pl. 2, Fig. 4) or crosscutting of burrows (Pl. 2, Fig. 5) by pyrite concretions, and similarity of silt (percentage composition and shape) contained within the concretions to that outside the concretions in the same layer. The fuzzy external boundary of the concretion in Plate 2, Figure 1, and the irregular development of pyrite in the interior of the concretion would not have survived transportation as a clast. The gradational boundary of the concretion in Plate 2, Figure 2 also precludes an origin as a transported clast.

Pyrite framboids exhibit a preference for primary pore spaces such as microfossils (PI. 2, Fig. 3) and for the more porous lithologies in any sample. Pyrite commonly forms an interstitial matrix between sand and coarse silt grains (Pl. 2, Fig. 3). Framboidal concretions are larger and more common in the coarser grained lithology within any given sample. In the pyritized microturbidite sand layer in Sample 141$862 \mathrm{~A}-1 \mathrm{H}-3,139-141 \mathrm{~cm}$, the pyrite has replaced the coarsest portions of the bed, and the primary basal troughs are perfectly outlined against the finer grained substrate (Pl. 2, Fig. 4). The coarse silt lining of the burrow in Plate 2, Figure 5, contains more pyrite framboids than the surrounding silty clay matrix; however, it is not clear why the large concentration of pyrite that crosscuts the burrow formed in that location. In another example (Pl. 2, Figs. 6 and 7), pyrite forms an interstitial fill around sand grains filling a burrow. The margin of the concretion is irregular, with isolated framboids appearing to colonize the area around it. In Plate 2, Figure 6, the framboids can be seen to sharply decrease at the boundary between the sand and silt of the burrowed area and the clay-rich material filling the vein structure next to the burrow, indicating that the finer grained lithology was a less favorable site for formation of pyrite framboids.

Pyrite framboids occur within microfossils such as foraminifers in many samples, ranging from thin coatings on the insides of tests to complete fillings of every chamber (Pl. 3, Figs. 1-3). In most cases it is not possible to determine the timing of such fillings, but the presence of fragile sprays of framboids that crosscut the walls of some microfossil tests and pass into the surrounding matrix indicates that deposition of the microfossil occurred before deposition of the pyrite framboids. The shallow depth at which many of the filled microfossils occur indicates that they are filled relatively quickly after deposition. Some samples contain numerous partially filled foraminifers in which the pyrite framboids are concentrated only in the lower parts of each chamber to form geopetal structures (Pl. 3, Figs. 1-3). Another type of geopetal structure is shown in Plate 3, Figure 4, in which a mat of pyrite framboids is draped over a microfossil test. The pyrite mat appears to have formed before the sediment was compacted, as it wraps down around the side of the shell. Although the shell itself is not filled, isolated framboids are disseminated throughout the interior of the shell as well as the surrounding sediment.

In Plate 3, Figure 5, pyrite framboids fill borings at the base of the shell. Eventually the entire area between inner and outer shell walls will be filled in so that the shell is outlined in pyrite (PI. 3, Fig. 6). It is unlikely that pyrite is actually replacing the shell material; Hendry (1993) has shown that pyrite fills voids in shell fragments and that the carbonate shell walls are later dissolved away, with more pyrite filling the new voids.

Pyrite also forms preferentially in organic-rich areas other than microfossils such as near fecal pellets. The ball of fecal pellets in Plate 3 , Figure 7 , hosts pyrite concretions which selectively replace some of the fecal pellets. Although none of the fecal pellets are themselves replaced by pyrite, framboidal concretions are common in the vicinity of fecal pellets, and almost all pellets observed have isolated small framboids sparsely disseminated within them.

\section{SEDIMENT DIAGENESIS AT SITE 862}

Site 862 , located at the crest of the Taitao Ridge, was predicted to be the most likely site of enhanced diagenesis and hydrothermal activity. Shipboard analysis confirmed that a number of diagenetic indicators (Table 3) at Site 862 are anomalous when compared with Sites 859-861 and 863. For example, organic hydrocarbons at this site are thermally mature, suggesting that the sediments were deposited on hot, hydrothermally active volcanic basement (Behrmann, Lewis, Musgrave, et al., 1992). The basal sediments (lower $4.25 \mathrm{~m}$ ) just above the volcanic rocks are thermally altered and mineralized, containing hydrothermal bornite, chalcopyrite, covellite, and pyrite; this interval exhibits an increase in the smectite/illite clay ratio and an anomalous thermal overprint in the remanent magnetism (Behrmann, Lewis, Musgrave, et al., 1992).

Only nine samples were collected from the thin $(\approx 22 \mathrm{~m})$ sediment blanket over the ridge. Although the data are incomplete, preliminary evidence suggests enhanced diagenesis even at shallow depths below the sea floor (Table 4). Point counts of shallow sediments from the northern transect (Sites 859-861) typically contain only $1 \%-1.5 \%$ disseminated pyrite framboids. In contrast, Sample 141-862A-1H-3, $139-141 \mathrm{~cm}$, obtained at $4.39 \mathrm{mbsf}$, contains $3 \%$ pyrite framboids disseminated throughout the average mud composition, and is distinguished by a microturbidite layer consisting of $78 \%$ framboidal pyrite filling pore spaces (Pl. 2, Fig. 4). Sample 141-862A-1H-4, 43-45 cm, obtained at a depth of 4.93 mbsf, contains silt layers with over $10 \%$ framboidal pyrite filling intergranular pore spaces (Table 4). In this sample, the pyritiferous layers are faulted, with additional pyrite framboids having formed within the fault zone after deformation. Many samples exhibit a strong preferred orientation in the clay minerals, also suggesting enhanced diagenesis, considering that these sediments are still soft and relatively uncompacted (Table 4). In Sample 141-862B-2W-CC, $27-29 \mathrm{~cm}$, collected at 21.54 mbsf just above the contact with pillow basalt, scattered pyrite framboids are present, but most of the metallic minerals are non-framboidal copper and iron sulfides (Table 4). Though not framboidal, these minerals are interstitial to clastic silt and sand particles, and therefore formed in place, presumably by hydrothermal processes.

Other than pyrite, diagenetic minerals at Site 862 are sparse. Phosphatic fish bones have been observed only in trace amounts; no authigenic phosphatic concretions, fecal pellets, or muds have been observed. Calcareous microfossils are lacking in the thin sections studied, so it is not possible to determine whether or not they have been dolomitized. Isotropic cloudy material interpreted as evidence of silica dissolution is present in every sample, as at other sites.

\section{MICROSTRUCTURES}

\section{Clay Fabric and Compaction Features}

Most samples exhibit at least a weak preferred orientation of tabular grains and clay minerals (Table 5). When observed in crosspolarized light with the gypsum plate as the stage is rotated, a majority of the clay minerals exhibit the same interference color (e.g., orange in the $+45^{\circ}$ position and blue in the $-45^{\circ}$ position). In general, this clay mineral fabric strengthens with depth, ranging from weakly developed in the top 10-20 meters of sediment, to moderately devel- 
Table 2. Diagenetic pyrite features in selected samples from Sites 859,861 , and 863 , arranged by depth.

\begin{tabular}{|c|c|c|c|c|c|c|c|c|}
\hline $\begin{array}{l}\text { Core, section. } \\
\text { interval (cm) }\end{array}$ & $\begin{array}{l}\text { Depth } \\
\text { (mbsf) }\end{array}$ & 1 & 2 & 3 & 4 & 5 & 6 & 7 \\
\hline \multicolumn{9}{|l|}{ 141-859A- } \\
\hline & $\begin{array}{r}4.58 \\
446\end{array}$ & $*$ & $\overline{+}$ & - & $"$ & - & " & - \\
\hline $\begin{array}{l}3 \mathrm{H}-3.76-78 \\
3 \mathrm{H}-4.95-97\end{array}$ & $\begin{array}{r}4.46 \\
16.46\end{array}$ & ? & - & - & z- & $=$ & - & $\bar{n}$ \\
\hline $\begin{array}{l}3 \mathrm{H}-4.95-97 \\
6 \mathrm{X}-2.55-57\end{array}$ & $\begin{array}{l}10.70 \\
36.75\end{array}$ & . & - & - & - & 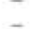 & $\overline{-}$ & 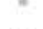 \\
\hline $6 \times-2,55-57$ & 56.75 & $=$ & . & - & - & 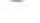 & - & - \\
\hline $8 X-C C .11-13$ & 80.61 & & - & - & - & - & - & - \\
\hline $11 X-3,143-145$ & 72.73 & $\%$ & - & - & - & - & * & - \\
\hline \multicolumn{9}{|l|}{$\begin{array}{l}141-859 \mathrm{~B}- \\
3 \mathrm{R}-7.14-16\end{array}$} \\
\hline $141-859 \mathrm{~A}-$ & & & & & & & & \\
\hline $16 \mathrm{X}-\mathrm{CC}, 30-32$ & 100.85 & * & - & - & - & - & - & - \\
\hline \multicolumn{9}{|l|}{$141-859 \mathrm{~B}-$} \\
\hline $\begin{array}{l}14 \mathrm{R}-4.48-50 \\
21 \mathrm{R}-2.43-45\end{array}$ & $\begin{array}{l}240.28 \\
304.73\end{array}$ & "it. & $\overline{-}$ & - & $\overline{-}$ & $\overline{-}$ & - & $\overline{-}$ \\
\hline $36 \mathrm{R}-2,22-24$ & 448.82 & * & - & - & - & - & - & - \\
\hline \multicolumn{9}{|l|}{ 141-860B- } \\
\hline $2 \mathrm{H}-3.65-76$ & 5.05 & in & e & - & - & - & - & - \\
\hline $\begin{array}{l}141-860 \mathrm{~A}- \\
1 \mathrm{H}-7.45-47\end{array}$ & 9.45 & $*$ & - & - & - & - & * & $\Rightarrow$ \\
\hline \multicolumn{9}{|l|}{$141-860 \mathrm{~B}-$} \\
\hline $3 \mathrm{H}-7.1-6$ & 19.91 & $=$ & - & * & * & * & - & - \\
\hline $4 \mathrm{H}-2.4 \mathrm{I}-43$ & 22.31 & * & " & - & - & * & - & - \\
\hline $7 \mathrm{H}-3,48-50$ & 52.38 & * & * & - & s & - & - & - \\
\hline $12 X-4,103-104$ & 93.23 & * & - & - & - & - & - & - \\
\hline $15 \times-3,7-9$ & 110.27 & : & - & $*$ & $=$ & - & - & - \\
\hline $16 \times-2,128-132$ & 119.58 & $=$ & - & - & $=$ & * & - & - \\
\hline $19 \times-4,11-13$ & 141.71 & 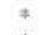 & ${ }^{4}$ & - & - & - & * & - \\
\hline $19 X-4.71-73$ & 142.31 & * & * & * & " & " & * & - \\
\hline $25 X-1,98-100$ & 195.08 & * & $=$ & - & - & - & - & - \\
\hline $33 \times-1,77-79$ & 271.97 & * & * & - & - & - & - & - \\
\hline $50 \times-2.139-141$ & 428.19 & 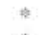 & 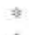 & - & - & - & - & - \\
\hline $50 X-3,21-25$ & 428.51 & " & * & - & - & - & - & $*$ \\
\hline $58 X-1.91-93$ & 493.71 & " & $\Rightarrow$ & - & $\%$ & * & - & $\phi$ \\
\hline $61 X-1.28-30$ & 521.98 & : & $=$ & - & - & - & - & - \\
\hline $67 \times-1.63-67$ & 579.83 & * & $=$ & $z$ & - & - & - & - \\
\hline $67 X-3.22-24$ & 582.42 & - & * & * & - & - & - & - \\
\hline \multicolumn{7}{|l|}{ 141-861B- } & $*$ & - \\
\hline $\begin{array}{l}141-861 \mathrm{C}- \\
2 \mathrm{H}-5,42-44\end{array}$ & 9.42 & * & - & * & * & * & - & - \\
\hline $\begin{array}{l}141-861 \mathrm{~A}- \\
\mathrm{IH}-4.18-20\end{array}$ & 10.18 & * & - & $n$ & $*$ & - & - & - \\
\hline
\end{tabular}

oped, and then strongly developed. Thin sections oriented at high angles to each other in the same sample show the same flattening, suggesting that the fabric is relatively uniform on a $1 \mathrm{~cm}$ scale. A striking example of clay mineral fabric is seen in the granule conglomerate of Sample 141-861C-36X-3, 58-60 cm (299.18 mbsf; Pl. 4, Fig. 1), in which each clast exhibits a strong internal fabric, the orientation of which is unique for each clast and different from the matrix. The compaction fabric within the matrix is parallel to primary bedding. Thus the clasts acquired their internal fabric prior to being deposited in the conglomerate bed, and the fabric within the matrix developed after deposition of the conglomerate bed. The matrix of this sample exhibits a moderate preferred orientation parallel to bedding. In the two slump folds examined (Samples 141-863B-6X-CC, 24-26 cm, and $-23 R-1,124-128 \mathrm{~cm}$ ), clay fabric was well developed in limbs parallel to bedding, but weak around the fold noses. This suggests that the clay fabric begins to develop earlier than the slump folding, probably during initial deposition and compaction to form layers with sufficient cohesion to slump, and is unable to completely reorient itself after slumping.

Compaction features include all features flattened in the plane of bedding, like the fecal pellet flattened and deformed against a shell fragment in Figure 2 of Plate 4. Other features observed to exhibit such flattening include authigenic phosphate concretions ("F-phosphates"), framboidal pyrite concretions, clastic mica grains, burrows, concretions of sponge spicules, and rarely, microfossils.

\begin{tabular}{|c|c|c|c|c|c|c|c|c|}
\hline $\begin{array}{l}\text { Core, section. } \\
\text { interval }(\mathrm{cm})\end{array}$ & $\begin{array}{l}\text { Depth } \\
(m b s f)\end{array}$ & 1 & 2 & 3 & 4 & 5 & 6 & 7 \\
\hline \multicolumn{9}{|l|}{$141-861 \mathrm{C}-$} \\
\hline $3 \mathrm{H}-3,128-130$ & 16.78 & \% & * & - & - & " & - & - \\
\hline $4 \mathrm{H}-3,39-4 \mathrm{I}$ & 25.39 & " & * & - & - & \% & * & - \\
\hline $7 \mathrm{H}-6,139-141$ & 59.39 & 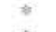 & - & - & - & - & - & - \\
\hline $8 \mathrm{H}-1.16-18$ & 60.16 & 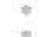 & * & - & * & " & - & - \\
\hline $12 X-2,34-37$ & 91.94 & " & * & - & - & - & - & - \\
\hline $14 X-2,22-24$ & 111.12 & is & - & - & - & - & - & - \\
\hline $16 \mathrm{X}-3.99-101$ & 132.89 & " & - & - & - & - & - & - \\
\hline $18 \mathrm{X}-2.28-30$ & 150.28 & 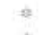 & - & - & 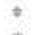 & * & - & - \\
\hline $22 X-2.31-33$ & 181.71 & $*$ & - & - & " & * & * & it \\
\hline $35 \mathrm{X}-3,82-85$ & 288.85 & s & $=$ & - & - & - & - & z \\
\hline $36 \times-3,58-60$ & 299.18 & s & \# & - & - & - & - & क \\
\hline $39 \times-3.58-60$ & 326.90 & $\Rightarrow$ & $*$ & - & - & - & - & - \\
\hline $\begin{array}{l}\text { I4I-86ID- } \\
16 \mathrm{R}-3,6-10\end{array}$ & 488.27 & " & - & - & - & - & * & - \\
\hline \multicolumn{9}{|l|}{$141-863 \mathrm{~A}-$} \\
\hline IH-4. 32-38 & 4.82 & " & - & - & - & - & * & * \\
\hline $1 \mathrm{H}-4.66-72$ & 5.16 & " & - & - & - & - & - & $=$ \\
\hline $2 \mathrm{H}-2,113-118$ & 11.23 & : & - & - & - & - & & * \\
\hline $4 \mathrm{H}-2.80-92$ & 29.90 & $*$ & * & - & - & - & " & - \\
\hline $6 \mathrm{H}-\mathrm{I}, 108-110$ & 47.68 & * & * & - & - & - & - & * \\
\hline $7 X-2,36-38$ & 57.96 & * & - & - & - & - & - & - \\
\hline $15 X-$-CC. $13-15$ & 133.53 & $*$ & - & - & - & - & - & - \\
\hline $18 \times-C C .17-19$ & 162.57 & * & - & - & - & - & - & - \\
\hline $21 X-1.40-42$ & 191.70 & $*$ & - & - & - & - & - & - \\
\hline $25 \times-2,16-18$ & 230.49 & क & " & - & - & - & * & - \\
\hline \multicolumn{9}{|l|}{$141-86.3 \mathrm{~B}-$} \\
\hline $\begin{array}{l}4 X-2.142-144 \\
6 X-\text { CC. } 24-26\end{array}$ & $\begin{array}{l}328.82 \\
345.44\end{array}$ & : & - & $\overline{-}$ & $\overline{-}$ & $\overline{-}$ & - & $\overline{-}$ \\
\hline $8 \mathrm{~N}-1,28-33$ & 357.68 & * & - & - & - & - & * & - \\
\hline IIR-1, 35-37 & 376.95 & $*$ & - & - & - & - & - & - \\
\hline $14 R-1.100-112$ & 406.50 & $1.5^{*}$ & - & - & - & * & - & \\
\hline $17 R-3.63-65$ & 438.03 & * & - & - & - & - & - & - \\
\hline 2|R-2.9|-95 & 474.99 & * & - & - & - & - & - & - \\
\hline $23 \mathrm{R}-1.124-128$ & 493.64 & * & - & - & - & - & * & - \\
\hline $37 \mathrm{R}-1.48-50$ & 627.48 & * & - & - & - & - & - & $*$ \\
\hline $39 \mathrm{R}-1.31-35$ & 646.61 & 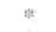 & - & - & - & - & - & - \\
\hline $4 \mid R-2.119-126$ & 668.19 & " & - & - & - & - & - & - \\
\hline $43 R-2.38-40$ & 686.68 & * & - & - & - & - & - & - \\
\hline $49 \mathrm{R}-1.53-56$ & 733.73 & $=$ & - & - & - & - & - & - \\
\hline
\end{tabular}

Notes: ${ }^{*}=$ observed, $-=$ not observed: 1 = widely disseminated pyrite framboids (\%): 2 = pyrite concretions: $3=$ geopetal fills and mats: $4=$ partially filled microfossils: $5=$ completely filled microfossils, $6=$ trains of pyrite framboids: $7=$ pyrite interstitial in layers.

\section{Vein Structures}

Vein structures have been recovered in cores from many different convergent margins (e.g., Lundberg and Moore, 1986; Lindsley-Griffin et al., 1990; Kemp and Lindsley-Griffin, 1990). Such features were recovered in Leg 141 cores at every site except Site 862 (Behrmann, Lewis, Musgrave, et al., 1992). In this paper, "vein structures" refers to thin planar or curviplanar seams or sets of seams, typically darker and finer grained than surrounding material, which consist of altered in-situ sediment plus dark irresolvable stain (Lundberg and Moore, 1986). Because "vein" is usually applied to fractures with a secondary mineral filling (Bates and Jackson, 1987), the term is not truly appropriate for the vein structures seen in cores.

Our shallowest sample that exhibits vein structure is Sample 141$860 \mathrm{~A}-1 \mathrm{H}-7,45-47 \mathrm{~cm}$. At this depth $(9.45 \mathrm{mbsf})$, the muds have already developed a clay mineral fabric parallel to bedding. The vein structure, located in silty clay below a sand layer, consists of a network of irregular bands about $150-200 \mu \mathrm{m}$ across, within which the clay particles are aligned parallel to the vein structure walls, roughly perpendicular to the bedding laminae.

Many of the vein structures are obvious in the cores as a slightly darker band of color; a typical example would be the contrast of light to medium gray (N7-8) seams in olive gray (5Y 5/1) silt or clay. However, in some thin sections vein structures are difficult to detect, appearing to be only slightly darker than the surrounding material in 
Table 3. Comparison of selected diagenetic parameters at Site 862 with Sites 859, 860, 861, and 863 (data from Shipboard Scientific Party, 1992).

\begin{tabular}{lccccc}
\hline \multicolumn{1}{c}{ Diagenetic parameter } & \multicolumn{5}{c}{ Depth (approximate mbsf) } \\
\hline & 862 & 859 & 860 & 861 & 863 \\
$\begin{array}{l}\text { Total sulfate reduction } \\
\text { (allowing methanogene- } \\
\text { sis) }\end{array}$ & None & $15-22$ & $15-55$ & 7.45 & $68-76$ \\
$\begin{array}{l}\text { Lithification: sediment } \\
\text { to "stone" }\end{array}$ & 6.0 & 23.5 & 88 & 209 & 120 \\
$\begin{array}{l}\text { Physical properties: de- } \\
\text { crease in porosity and } \\
\text { water content }\end{array}$ & None & 200 & 90 & 200 & 100 \\
$\begin{array}{l}\text { Lowest diatoms in core- } \\
\text { catcher sample (silica } \\
\text { dissolution) }\end{array}$ & 0.15 & 265 & 310 & 328 & 260 \\
$\begin{array}{l}\text { Clay mineral smectite } \\
\begin{array}{l}\text { Hydrothermal minerals } \\
\text { (fault) }\end{array}\end{array}$ & 21.0 & None & None & None & None \\
\hline
\end{tabular}

plane light (PI. 4, Fig. 3). In cross-polarized light the features may nearly disappear, seeming to be subisotropic. With the gypsum plate, preferred orientation of the clay minerals within the zone is enhanced, and the feature becomes somewhat better defined (PI. 4, Fig. 4).

Some vein structures are more readily visible in thin section because their "filling" is a different composition than the surrounding material. For example, in Sample 141-861D-16R-3, 6-10 cm (Pl. 4, Fig. 5), vein structures consisting of silty clay exist within host material of clayey silt; both lithologies have enough clay for the vein structures to stand out because of the angular relationship between clay fabrics in the veins and in the host material. The anastomosing array of vein structures divides the massive host sediment into tabular and wedge-shaped panels. Some vein structures consist of multiple sets of seams, with the older ones being crosscut by younger ones whose internal clay fabric overprints the fabric in the older veins.

Some examples of vein structures that are partially infilled with silt or fine sand have been observed where vein structures cross silt or sand layers. In such cases, a plume of coarser grains streams stratigraphically upwards along the vein structure, suggesting that the grains are being transported along the plane of the structure. In Sample 141$863 \mathrm{~B}-7 \mathrm{~N}-2,71-73 \mathrm{~cm}$ (Pl. 4, Fig. 6), multiple vein structures crosscut a flattened, silt-filled burrow, obliterating part of it and apparently transporting part of the silt away. Because the opposite sides of the structure have not moved relative to each other, this feature cannot be explained by faulting and cataclasis. Other examples of sand and silt being transported along vein structures have been observed in Samples 141-859A-13X-CC, 21-23 cm, -860B-15X-3, 7-9 cm, -50X-2, 139$141 \mathrm{~cm}$, and -863B-14R-1, 100-112 cm. In Sample 141-863B-14R-1, $100-112 \mathrm{~cm}$, point counts of both vein and host material show that the average sediment contains $13 \%$ quartz clasts, whereas the vein contains $19 \%$ quartz clasts. It is not clear whether this is the result of coarser material being transported into the vein, or finer material being transported out of the vein (by dissolution?).

\section{Faults and Microfaults}

The term "deformation band" was used aboard ship for light or dark seams along which deformation has occurred, with visible separation or termination of primary features, including faults, shear bands, shear zones, and kink bands (Behrmann, Lewis, Musgrave, et al., 1992). Because the term "deformation band" is more commonly used for deformation within a single mineral grain (Hobbs et al.. 1976; Bates and Jackson, 1987), the terms "fault" or "microfault" are used in this paper. "Microfault" is a surface visible only under a microscope, in which one side has been displaced relative to the other (Twiss and Moores, 1992). "Cataclastic fabric" within faults and microfaults is
Table 4. Diagenesis and hydrothermal alteration in sediments at Site 862.

\begin{tabular}{|c|c|c|c|c|c|c|c|}
\hline $\begin{array}{l}\text { Core, section, } \\
\text { interval }(\mathrm{cm})\end{array}$ & $\begin{array}{l}\text { Depth } \\
\text { (mbsf) }\end{array}$ & 1 & 2 & 3 & 4 & 5 & 6 \\
\hline \multicolumn{8}{|l|}{$141-862=$} \\
\hline C-IH-I. 22-24 & 0.22 & & & NA & & & \\
\hline A- $1 \mathrm{H}-1.65-67$ & 0.65 & & & NA & & & \\
\hline $\mathrm{A}-1 \mathrm{H}-3,139-141$ & 4.39 & 3 & 78 & $*$ & * & - & - \\
\hline $\mathrm{A}-1 \mathrm{H}-4,43-45$ & 4.93 & 1 & 11 & - & * & - & - \\
\hline A- $2 \mathrm{H}-3,62-64$ & 9.02 & 4 & - & 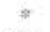 & - & - & - \\
\hline A $-3 \mathrm{H}-2,90-92$ & 17.30 & & & NA & & & \\
\hline A- $3 \mathrm{H}-4,25-27$ & 19.65 & * & * & - & $\pi$ & - & - \\
\hline A- $3 \mathrm{H}-4.70-75$ & 20.10 & & & NA & & & \\
\hline B-2W-CC. $27-29$ & 21.54 & $\rightarrow$ & - & - & - & $*$ & $*$ \\
\hline \multicolumn{8}{|c|}{$\begin{array}{l}\text { Notes: }{ }^{*}=\text { observed, }-=\text { not observed: } 1=\text { widely disseminated pyrite framboids } \\
(\%): 2=\text { framboidal pyrite concentrated in layers }(\%) ; 3=\text { framboidal pyrite } \\
\text { concretions present: } 4=\text { strong preferred orientation in clays: } 5=\text { hematite } \\
\text { (not observed at other sites) } 6=\text { copper minerals and non-framboidal pyrite } \\
\text { of hydrothermal origin: } \mathrm{NA}=\text { not available: thin section not available at time } \\
\text { of writing. }\end{array}$} \\
\hline
\end{tabular}

defined by the presence of broken and disaggregated grains, resulting in reduction of grain size (Lucas and Moore, 1986; Lundberg and Moore, 1986; Aalto, 1989). Movement along vein structures places them in the category of faults. Such movement is difficult to recognize unless it causes termination or separation of earlier structures, or produces cataclastic fabric. The "filling" of many vein structures and faults is almost the same composition as the surrounding material, except for a slight increase in the amount of irresolvable or isotropic material and a decrease in the grain size. Thus, although the vein structures in Plate 4, Figures 3 and 4 , could be faults with reduced grain size typical of cataclastic fabric, actual grain breakage cannot be demonstrated.

Like vein structures, faults and microfaults exhibit preferred orientation of clay minerals within the fault zone. For example, a microfault in Sample 141-863A-7X-2, 36-38 cm, consists of a zone of anastomosing traces within which clays have a strong preferred orientation parallel to the fault walls; outside the fault, clays have a strong preferred orientation parallel to bedding. Faults can be seen to predate pyrite formation in some cases where pyrite crosses the veins without interruption (e.g., Sample 141-861D-16R-3, 6-10 cm).

Where faults clearly crosscut and offset bedding and other features, they commonly appear to have behaved as ductile shear zones. In Sample 141-860B-50X-2, 139-141 cm, layers of silt, silty clay, and concentrations of fecal pellets are offset along multiple shears ( $\mathrm{Pl}$. 5, Fig. 1). A closeup view of one of the faults (Pl. 5, Fig. 2) reveals a zone $200-300 \mu \mathrm{m}$ wide, along which a fecal pellet is smeared. The more plastic behavior exhibited by the fecal pellet and the distribution of separation across the fault zone suggests that faulting occurred before the sediment was firmly lithified, or at least under low effective confining pressure (Cowan, 1982). The style of disruption of the silt bed in this sample supports this inference. Other evidence for early deformation was observed in Samples 141-862A-1H-4, 43-45 cm, and $-863 \mathrm{~B}-21 \mathrm{R}-2,91-95 \mathrm{~cm}$, in which pyrite framboids apparently cross the faults without being deformed, suggesting that they formed after the faults.

If faulting generally occurred early in the history of the sediments and rocks recovered on Leg 141 (as would be predicted in view of its tectonic setting), it would seem logical to expect that faults and fractures would serve as conduits for fluids being expelled during compaction and lithification. Evidence for fluid flow along faults is weak in Leg 141 samples, although previous work has suggested that limited fluid flow does occur along at least some microfaults (Knipe, 1986a, 1986b; Kemp and Lindsley-Griffin, 1990; Lindsley-Griffin et al., 1990). In Sample 141-860B-67X-3, 22-24 cm, the occurrence of pyrite stringers within and parallel to the microfaults (Pl. 5, Figs. 3 and 4) suggests that deposition of framboidal pyrite was enhanced along the fault, possibly due to fluids flowing along the fault. 
Table 5. Microstructural features in selected samples, arranged by depth and site.

\begin{tabular}{|c|c|c|c|c|c|c|c|c|}
\hline $\begin{array}{l}\text { Core, section. } \\
\text { interval (cm) }\end{array}$ & $\begin{array}{l}\text { Depth } \\
\text { (mbsf) }\end{array}$ & 1 & 2 & 3 & 4 & 5 & 6 & 7 \\
\hline \multicolumn{9}{|l|}{$141-859 \mathrm{~A}-$} \\
\hline $2 \mathrm{H}-3,38-40$ & 4.58 & w & - & - & - & - & - & - \\
\hline $3 \mathrm{H}-3,76-78$ & 14.46 & w & * & - & - & - & - & - \\
\hline $3 \mathrm{H}-4,95-97$ & 16.46 & $\mathrm{~m}$ & - & - & - & - & - & - \\
\hline $6 X-2,55-57$ & 36.75 & $\mathrm{~m}$ & - & * & - & - & - & - \\
\hline $8 \mathrm{X}-\mathrm{CC} \cdot 11-13$ & 50.61 & w & - & - & - & - & - & - \\
\hline $11 X-3,143-145$ & 72.73 & $s$ & $*$ & - & - & - & - & - \\
\hline 1.3X-CC, $21-23$ & 79.29 & $\mathrm{~m}$ & - & - & * & - & - & - \\
\hline $16 \mathrm{X}-\mathrm{CC} .30-32$ & 100.85 & w & - & - & - & - & - & - \\
\hline \multicolumn{9}{|l|}{$141-859 \mathrm{~B}$} \\
\hline $14 R-4,48-50$ & 240.28 & $\mathrm{~s}$ & - & - & - & - & - & - \\
\hline $21 \mathrm{R}-2,43-45$ & 304.73 & $s$ & - & - & - & - & - & - \\
\hline $36 \mathrm{R}-2,22-24$ & 448.82 & $s$ & - & - & - & - & - & - \\
\hline \multicolumn{9}{|l|}{$141-860 \mathrm{~B}-$} \\
\hline $2 \mathrm{H}-3,65-76$ & 5.05 & w & - & - & - & - & - & - \\
\hline \multicolumn{9}{|l|}{$141-860 \mathrm{~A}$} \\
\hline $\mathrm{IH}-7.45-47$ & 9.45 & - & - & * & - & - & - & - \\
\hline \multicolumn{9}{|l|}{$141-860 \mathrm{~B}-$} \\
\hline $3 \mathrm{H}-7.1-6$ & 19.91 & w & - & \# & - & - & - & - \\
\hline $4 \mathrm{H}-2,4 \mathrm{I}-43$ & 22.31 & - & - & - & - & - & - & - \\
\hline $7 \mathrm{H}-3.48-50$ & 52.38 & w & - & - & - & - & - & - \\
\hline $12 X-4,103-104$ & 93.23 & s & - & - & - & - & - & - \\
\hline $15 \times-3,7-9$ & 110.27 & - & - & * & - & - & - & - \\
\hline $16 \times-2,128-132$ & 119.58 & w & - & - & - & - & - & - \\
\hline $19 \times-4.11-13$ & 141.71 & w & - & * & - & - & - & - \\
\hline $19 X-4,71-73$ & 142.31 & $s$ & * & - & - & - & - & - \\
\hline $25 \mathrm{X}-1.98-100$ & 195,08 & - & - & - & - & - & - & - \\
\hline $33 \times-1,77-79$ & 271.97 & w & - & - & - & - & - & - \\
\hline $50 \times-2,139-141$ & 428.19 & - & - & - & * & - & * & - \\
\hline $50 \times-3,21-25$ & 428.51 & $\mathrm{~m}$ & - & - & - & - & - & - \\
\hline $58 \times-1.91-93$ & 493.71 & - & - & - & - & - & - & - \\
\hline $61 \times-1.28-30$ & 521.98 & w & - & " & - & - & 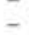 & - \\
\hline $67 X-1.63-67$ & 579.83 & w & - & - & - & - & - & - \\
\hline $67 X-3,22-24$ & 582.42 & - & - & - & - & - & - & - \\
\hline \multicolumn{9}{|l|}{$141-861 \mathrm{~A}-$} \\
\hline \multirow{2}{*}{\multicolumn{9}{|c|}{$|4|-86 \mid \mathrm{B}$}} \\
\hline & & & & & & & & \\
\hline \multicolumn{9}{|l|}{$141-861 \mathrm{C}$. } \\
\hline $2 \mathrm{H}-5,42-44$ & 9.42 & w & $=$ & - & - & - & - & - \\
\hline $3 \mathrm{H}-3,128-1,30$ & 16.78 & - & - & - & - & - & - & - \\
\hline
\end{tabular}

An example of an offset pyrite concretion is shown in Plate 5, Figures 5 and 6 (Sample 141-861D-16R-3, 6-10 cm). A closeup view of the fault zone shows that the pyrite concretion is offset like a deck of cards along a series of discrete shear planes distributed across the fault zone. This is an example of a pyrite concretion that pre-dates the fault being offset by it, yet elsewhere in the same sample, delicate sprays of framboids cross fault margins without displacement, suggesting that framboid growth continued after faulting.

\section{SUMMARY AND CONCLUSIONS}

Phosphates occur as clasts, phosphatic fecal pellets, phosphatic mud, and rare concretions in samples from the Chile Triple Junction. Clastic apatite or fluorapatite fish debris is ubiquitous in trace amounts; hard clear phosphatic nodules of probable clastic origin occur in some sand- and silt-sized material. Some, but not all, fecal pellets are phosphatic. Concretions of phosphates and areas of dispersed phosphatic mud formed in place. The source of phosphorus to form apatite in the phosphatic concretions and muds is probably fish debris (Suess, 1981).

Many calcareous microfossil tests are partially to completely dolomitized. Carbonate veins, burrow fillings, and cement are best developed in cores from Site 863. Sample et al. (1993) have shown that carbonate veins and carbonate cement in samples from the Cascadia accretionary complex form during diagenesis from fluids squeezed out of the sediments during accretion. The carbonate cement and veins observed at Site 863 may have formed in a similar fashion.

\begin{tabular}{|c|c|c|c|c|c|c|c|c|}
\hline $\begin{array}{l}\text { Core, section. } \\
\text { interval }(\mathrm{cm})\end{array}$ & $\begin{array}{l}\text { Depth } \\
\text { (mbsf) }\end{array}$ & 1 & 2 & 3 & 4 & 5 & 6 & 7 \\
\hline $4 \mathrm{H}-3,39-41$ & 25.39 & - & - & - & - & - & - & - \\
\hline $7 \mathrm{H}-6,139-141$ & 59.39 & s & - & - & - & - & - & - \\
\hline $8 \mathrm{H}-1,16-18$ & 60.16 & - & 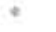 & - & - & - & - & - \\
\hline $12 X-2,34-37$ & 91.94 & $s$ & - & - & - & - & - & - \\
\hline $14 X-2,22-24$ & 111.12 & $s$ & - & - & - & - & - & - \\
\hline $16 \mathrm{X}-3,99-101$ & 132.89 & - & - & - & - & - & - & - \\
\hline $18 X-2,28-30$ & 150.28 & - & - & - & - & - & - & - \\
\hline $22 X-2,31-33$ & 181.71 & - & * & - & - & - & - & - \\
\hline $35 X-3.82-85$ & 288.85 & $s$ & $*$ & - & - & - & - & - \\
\hline $36 \times-3,58-60$ & 299.18 & $s$ & - & - & - & - & - & - \\
\hline $39 X-3,58-60$ & 326.90 & - & - & - & - & - & - & - \\
\hline $\begin{array}{l}141-861 \mathrm{D}- \\
16 \mathrm{R}-3,6-10\end{array}$ & 488.27 & s & - & * & * & - & - & - \\
\hline $141-863 \mathrm{~A}-$ & & & & & & & & \\
\hline IH $-4,32-38$ & 4.82 & w & - & - & - & क & - & - \\
\hline $\begin{array}{l}\mathrm{H}-4,66-72 \\
2 \mathrm{H}-2\end{array}$ & 5.16 & - & - & - & - & - & - & - \\
\hline $\begin{array}{l}2 \mathrm{H}-2,113-118 \\
4 \mathrm{H}-2,90-92\end{array}$ & 11.23 & - & - & - & - & $\Rightarrow$ & - & - \\
\hline $4 \mathrm{H}-2,90-92$ & 29.90 & $w$ & - & - & - & - & - & - \\
\hline $6 \mathrm{H}-1,108-110$ & 47.68 & $\mathrm{~m}$ & - & at & $*$ & $*$ & - & - \\
\hline $7 X-2,36-38$ & 57.96 & $\mathrm{~m}$ & - & 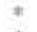 & $\Rightarrow$ & - & - & - \\
\hline $15 X-C C .13-15$ & 1.33 .53 & - & - & $*$ & $\Rightarrow$ & - & - & - \\
\hline $18 \times-C C .17-19$ & 162.57 & $m$ & - & - & - & - & - & - \\
\hline $21 X-1.40-42$ & 191.70 & $\mathrm{~m}$ & - & - & - & - & - & - \\
\hline $25 X-2.16-18$ & 230.49 & - & $-\cdot$ & - & - & - & - & - \\
\hline \multicolumn{9}{|l|}{$141-863 \mathrm{~B}-$} \\
\hline $\begin{array}{l}4 X-2,142-144 \\
6 X-C C .24-26\end{array}$ & 328.82 & $\mathrm{~m}$ & - & $*$ & - & - & - & - \\
\hline $6 \mathrm{X}-\mathrm{CC}, 24-26$ & 345.44 & - & - & - & - & * & - & - \\
\hline $8 \mathrm{~N}-1.28-33$ & 357.68 & $s$ & - & $*$ & * & $*$ & - & - \\
\hline IIR-1, 35-37 & 376.95 & $s$ & - & 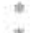 & - & - & - & - \\
\hline $17 \mathrm{R}-3,63-65$ & 438.03 & $\mathbf{s}$ & - & * & - & - & - & - \\
\hline $2 \mid R-2,91-95$ & 474.99 & s & - & $*$ & - & $*$ & - & - \\
\hline $23 R-1.124-128$ & 493.64 & $s$ & - & - & - & - & * & - \\
\hline $37 R-1.48-50$ & 627.48 & m & - & $*$ & - & - & - & - \\
\hline $39 \mathrm{R}-1,31-35$ & 646.61 & s & - & * & * & $*$ & - & * \\
\hline $41 R-2,119-126$ & 668.19 & - & - & - & * & - & - & \$ \\
\hline $43 R-2,38-40$ & 686.68 & - & - & - & * & - & - & - \\
\hline $49 R-1.53-56$ & 733.73 & - & - & - & * & - & - & " \\
\hline
\end{tabular}

The "unidentified amorphous phase" observed in shipboard XRD samples may be silica derived from devitrification of volcanic glass or dissolution of siliceous microfossils. Clouds of an isotropic material resembling amorphous silica (Opal-A or Opal-CT) were observed in almost every thin section, in some cases localized around devitrifying volcanic glass.

Pyrite concretions form best in organic-rich environments and in the more porous materials, especially in and around microfossil tests and shell fragments. In geopetal structures, pyrite selectively fills the stratigraphically lower part of microfossil chambers, or drapes over the top of intact tests. In some cases, pyrite framboids fill borings or spaces between the walls of foraminifer tests, giving them the appearance of having been replaced by pyrite. However, no evidence of actual replacement of shell material by pyrite has been observed.

Evidence supporting the early formation of authigenic pyrite is plentiful. Even the shallowest samples studied, collected within the top few meters of sediment, contain framboidal pyrite. Such shallow sediments are above the zone of almost complete sulfate reduction determined from interstitial water compositions (Table 3 ), suggesting that the process of sulfate reduction itself facilitates the formation of framboidal pyrite.

At Site 862 , many diagenetic processes appear to be enhanced relative to other sites (Table 3 ), supporting the hypothesis that sediments were deposited directly on a hydrothermally active, warm Taitao Ridge. Disseminated framboidal pyrite occurs in greater concentrations in samples from Site 862, and many layers rich in fram- 
boidal pyrite appear in the upper part of the sedimentary column. In contrast, rocks in the lower $4-5 \mathrm{~m}$, just above the depositional contact with volcanic rocks, exhibit hydrothermal pyrite and copper sulfides in addition to sparse framboidal pyrite.

Compaction fabric is expressed by subparallel alignment of tabular grains and clay minerals, and tends to strengthen with depth. It is best developed in the clay-rich samples. Contrasts in the strength of this preferred orientation are seen across hypothesized faults. In slump folds, the preferred orientation is weaker in the fold noses than in the limbs, indicating that only partial reorientation of grains occurred after formation of the slump fold. In samples from the vertically bedded interval of Site 863, the fabric is bedding-parallel. Thus, the clay fabric begins to form very early in the history of the sediment, and its orientation relative to primary bedding is unlikely to change greatly once lithification begins unless special conditions are present.

The fabric parallel to walls of vein structures and faults may be the result of such special conditions. Although it might be argued that shearing along faults facilitates reorientation of clay particles by rotation, such a mechanism cannot be invoked for vein structures that cross layers without causing visible separation. Instead, the alignment of clay minerals parallel to vein structure walls must be due to pressure solution and redeposition enhanced by fluid flow along the veins. Framboidal pyrite is localized along some faults and vein structures, and both deformed pre-faulting pyrite concretions and undeformed post-movement concretions may appear in the same sample. Both sand and silt grains appear to have been transported along some vein structures by fluid flow.

\section{ACKNOWLEDGMENTS}

The authors thank the Ocean Drilling Program and the Leg 141 Shipboard Scientific Party for helping collect the samples used in this study. We also thank Kenneth R. Aalto and Suzanne O'Connell for their careful and helpful reviews. The manuscript was further improved by the editors at ODP. Sample preparation and analysis was supported by a grant from the JOI U.S. Science Support Program.

\section{REFERENCES ${ }^{*}$}

Aalto, K.R., 1989. Franciscan depositional setting based on early-formed structures in debris flow deposits and turbidites, Point St. George, northern California. In Colburn, I.P., Abbott, P.L., and Minch, J. (Eds.), Conglomerates in Basin Analysis: A Symposium Dedicated to A.O. Woodford. Soc. Econ. Paleontol. Mineral., Pacific Sect., 62:169-178.

Bates, R.L., and Jackson, J.A. (Eds.), 1987. Glossary of Geology (3rd ed.): Alexandria, VA (American Geological Institute).

Behrmann, J.H., Lewis, S.D., Musgrave, R.J., et al., 1992. Proc. ODP, Init. Repts., 141: College Station, TX (Ocean Drilling Program).

Cowan, D.S., 1982. Deformation of partly dewatered and consolidated Franciscan sediments near Piedras Blancas Point, CA. In Leggett, J.K. (Ed.), Trench-Forearc Geology: Sedimentation and Tectonics on Modern and Ancient Active Plate Margins. Geol. Soc. Spec. Publ. London, 10:439 457.

Forsythe, R., and Prior, D., 1992. Cenozoic continental geology of South America and its relations to the evolution of the Chile Triple Junction. In Behrmann, J.H., Lewis, S.D., Musgrave, R.J., et al., Proc. ODP, Init. Repts., 141: College Station, TX (Ocean Drilling Program), 23-31.
Garrison, R.E., and Kastner, M., 1990. Phosphatic sediments and rocks recovered from the Peru margin during ODP Leg 112. In Suess, E., von Huene, R., etal., Proc. ODP, Sci. Results, 112: College Station, TX (Ocean Drilling Program), 111-134.

Griffin, J.R., and Lindsley-Griffin, N., 1992. Textures, microstructures, and lithologies of Japan Sea sediments from the lower portion of Hole 799B, Leg 128. In Pisciotto, K.A., Ingle, J.C., Jr., von Breymann, M.T., Barron, J., et al., Proc. ODP, Sci. Results, $127 / 128$ (Pt. 1): College Station, TX (Ocean Drilling Program), 33-48.

Hendry, J.P., 1993. Calcite cementation during bacterial manganese, iron and sulphate reduction in Jurassic shallow marine carbonates. Sedimentology, 40:87-106.

Hobbs, B.E., Means, W.D., and Williams, P.F., 1976. An Outline of Structural Geology: New York (Wiley).

Kemp, A.E.S., and Lindsley-Griffin, N., 1990. Variations in structural style within Peruvian forearc sediments. In Suess, E., von Huene, R., et al., Proc. ODP, Sci. Results, 112: College Station, TX (Ocean Drilling Program), 17-31.

Knipe, R.J., 1986a. Faulting mechanisms in slope sediments: examples from Deep Sea Drilling Project cores. In Moore, J.C. (Ed.), Structural Fabric in Deep Sea Drilling Project Cores from Forearcs. Mem.-Geol. Soc. Am., 166:45-54.

1986b. Microstructural evolution of vein arrays preserved in Deep Sea Drilling Project cores from the Japan Trench, Leg 57. In Moore, J.C. (Ed.), Structural Fabric in Deep Sea Drilling Project Cores from Forearcs. Mem.-Geol. Soc. Am., 166:75-87.

Lindsley-Griffin, N., Kemp, A., and Swartz, J.F., 1990. Vein structures of the Peru Margin, Leg 112. In Suess, E., von Huene, R., et al., Proc. ODP, Sci. Results, 112: College Station, TX (Ocean Drilling Program), 3-16.

Lucas, S.E., and Moore, J.C., 1986. Cataclastic deformation in accretionary wedges: Deep Sea Drilling Project Leg 66, southern Mexico, and on-land examples from Barbados and Kodiak Islands. In Moore, J.C. (Ed.), Structural Fabric in Deep Sea Drilling Project Cores from Forearcs. Mem.Geol. Soc. Am., 166:89-103.

Lundberg, N., and Moore, J.C., 1986. Macroscopic structural features in Deep Sea Drilling Project cores from forearc regions. In Moore, J.C. (Ed.), Structural Fabric in Deep Sea Drilling Project Cores From Forearcs. Mem.-Geol. Soc. Am., 166:13-44.

Sample, J.C., Reid, M.R., Tobin, H.J., and Moore, J.C., 1993. Carbonate cements indicate channeled fluid flow along a zone of vertical faults at the deformation front of the Cascadia accretionary wedge (northwest U.S. coast). Geology, 21:507-510.

Suess, E., 1981. Phosphate regeneration from sediments of the Peru continental margin by dissolution of fish debris. Geochim. Cosmochim. Acta. 45:577-588.

Swartz, J.F., and Lindsley-Griffin, N., 1990. An improved impregnation technique for studying structure of unlithified cohesive sediments. In Suess. E., von Huene, R., et al., Proc. ODP. Sci. Results, 112: College Station, TX (Ocean Drilling Program), 87-91.

Twiss, R.J., and Moores, E.M., 1992. Structural Geology: New York (Freeman). Abbreviations for names of organizations and publications in ODP reference lists follow
the style given in Chemical Abstracts Service Source Index (published by American
Chemical Society).

Date of initial receipt: 26 August 1993

Date of acceptance: 28 February 1994

Ms 141SR-003 

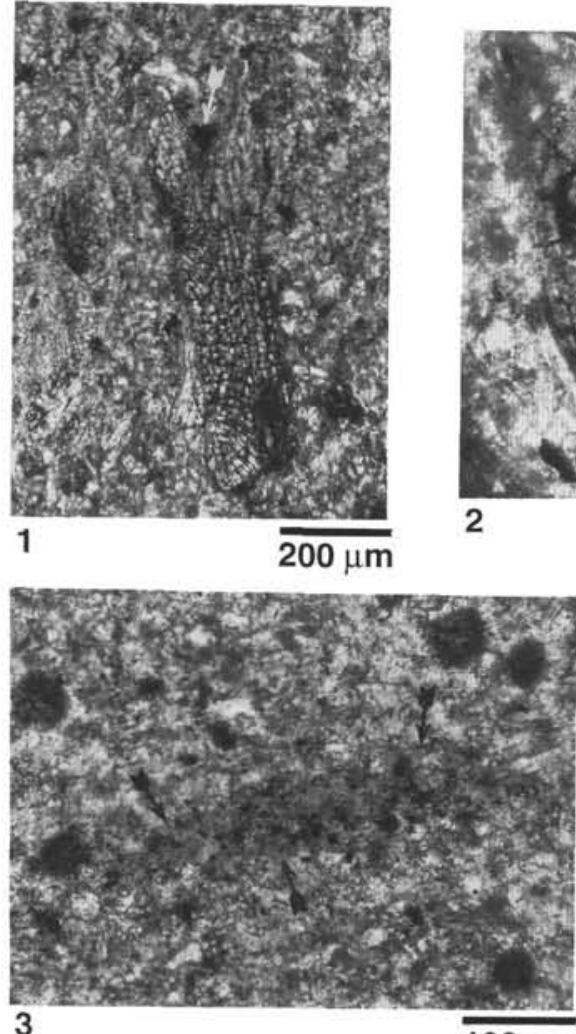

3
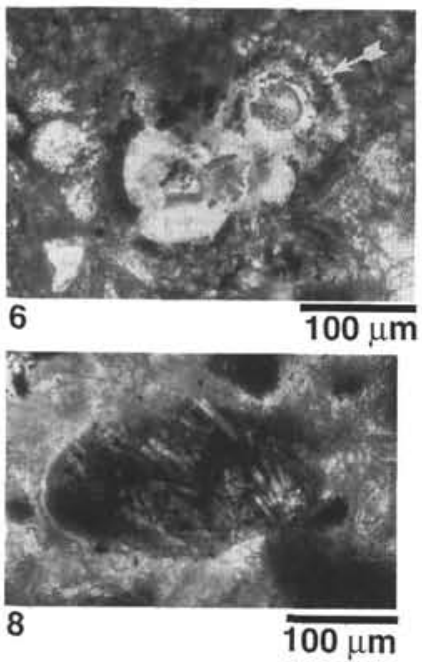
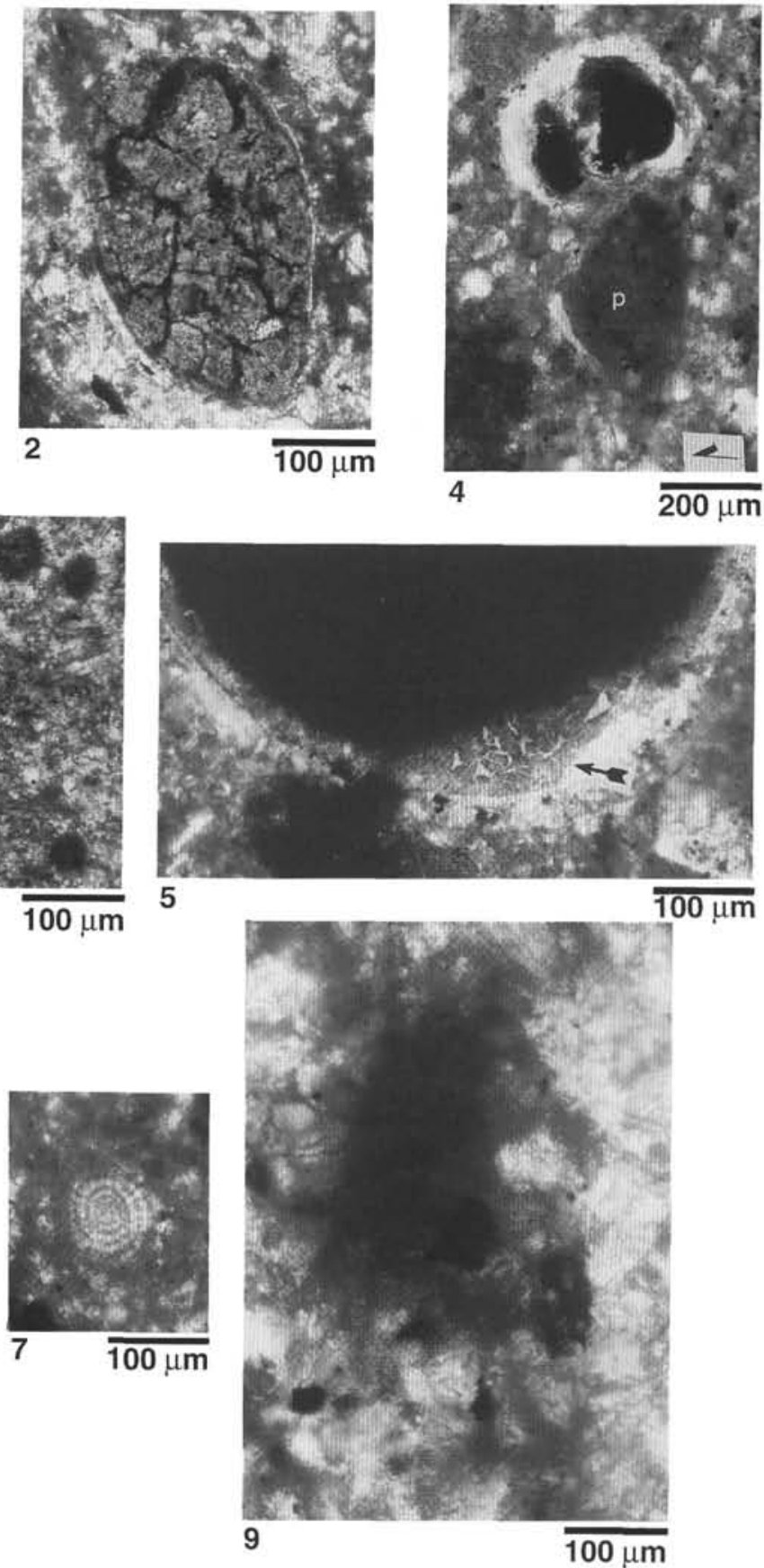

Plate 1. Photomicrographs of phosphate, dolomite, and silica. Single-bar arrow indicates direction of stratigraphic tops. 1. Fish-bone fragments with a small cluster of pyrite framboids (arrow), plane light; Sample 141-860B-19X-4, $71-73 \mathrm{~cm}$. 2. Hard phosphatic nodule, probably clastic, plane light; Sample 141-860B-58X-1, 91-93 cm. 3. Soft friable phosphate concretion (arrows), probably authigenic, $184.57 \mathrm{mbsf}$, plane light; Sample 141-861C-22X-4, 17-19 $\mathrm{cm}$. 4. Phosphatic fecal pellet containing sparse pyrite framboids ("p") adjacent to foraminifer with geopetal filling of pyrite framboids, 19.91 mbsf, plane light; Sample 141-860B-3H-7, 1-6 cm. 5. Bored foraminifer shell (arrow) partially replaced by dolomite and filled with pyrite framboids, $493.71 \mathrm{mbsf}$, plane light with Alizarin Red-S stain for calcite; Sample 141-860B-58X-1, 91-93 cm. 6. Partially dolomitized foraminifer shell, arrow on dolomite, 493.71 mbsf, plane light with Alizarin Red-S stain for calcite; Sample 141-860B-58X-1,91-93 cm. 7. Siliceous microfossil (diatom) at $181.71 \mathrm{mbsf}$, plane light; Sample $141-861 \mathrm{C}-22 \mathrm{X}-2,31-33 \mathrm{~cm}$. 8. Partly devitrified microlitic volcanic glass silt grain (150-245 $\mu \mathrm{m}), 9.45 \mathrm{mbsf}$, plane light; Sample 141-860A-1H-7, $45-47 \mathrm{~cm}$. 9. Cloud of isotropic amorphous phase around devitrified volcanic glass, 426.86 mbsf, plane light; Sample 141-863B-16R-2, 66-68 cm. 

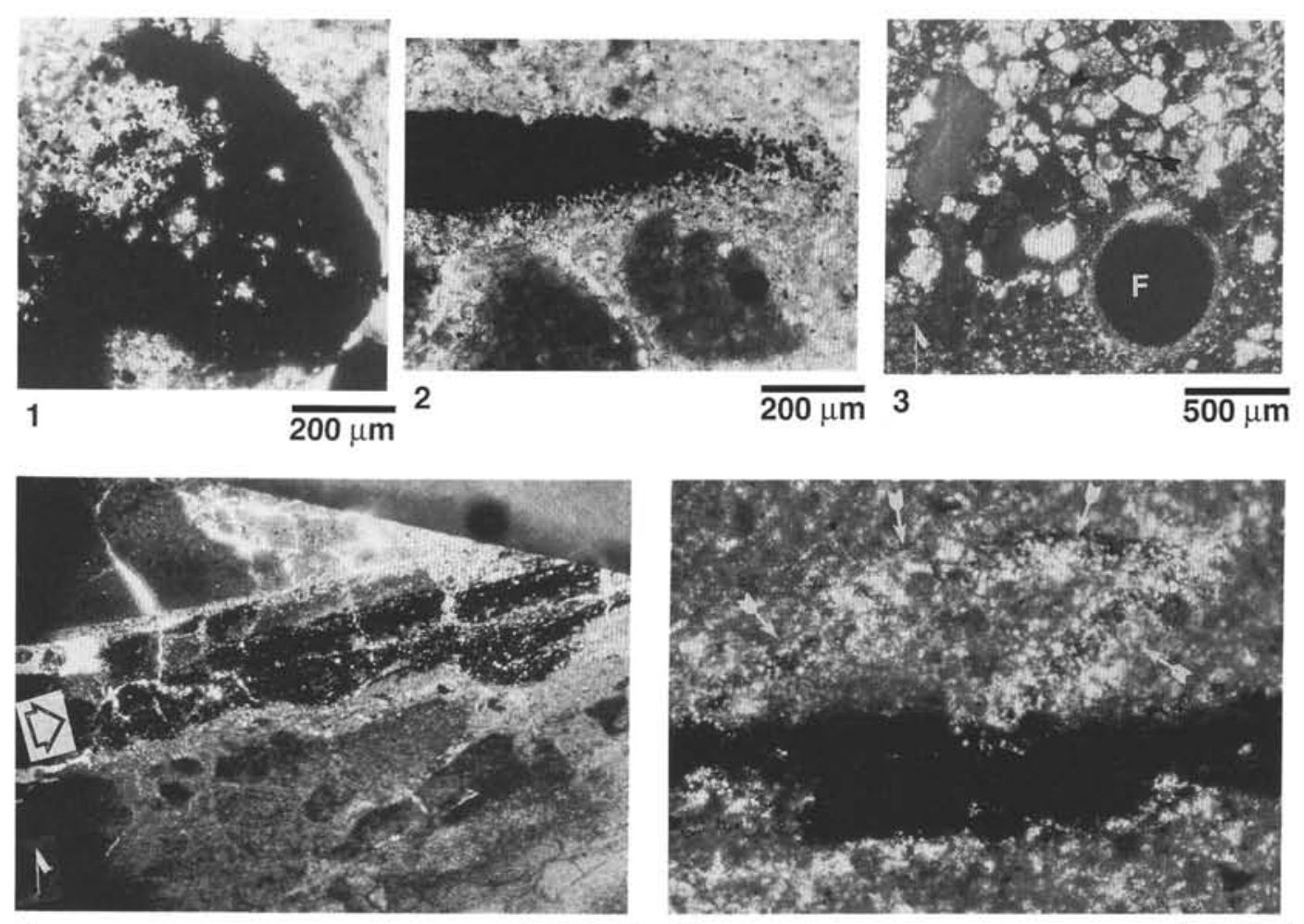

4

$\overline{200 \mu \mathrm{m}} 5$

$\overline{200 \mu \mathrm{m}}$

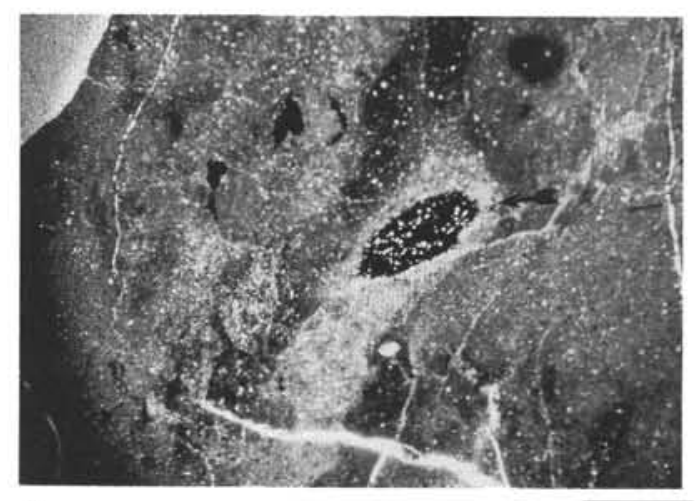

6

$2 \mathrm{~mm}$

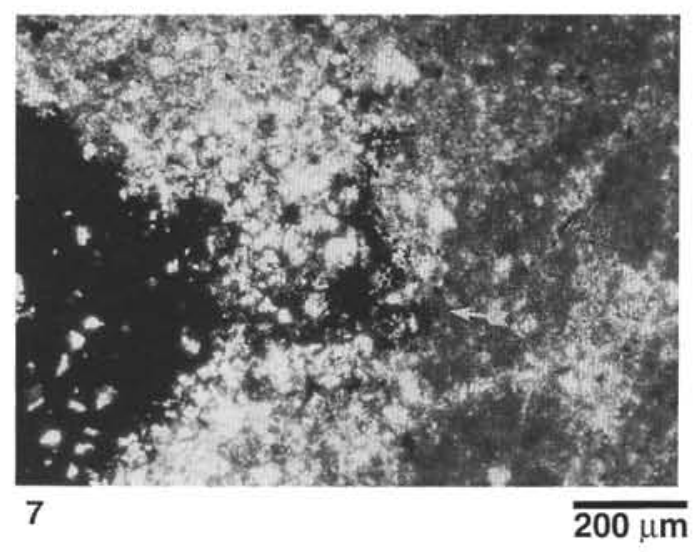

Plate 2. Photomicrographs of authigenic iron sulfides. Single-bar arrow indicates direction of stratigraphic tops in Figs. 3 and 4. 1-2. Pyrite concretions in gravel unit at $60.16 \mathrm{mbsf}$, plane light; Sample $141-861 \mathrm{C}-8 \mathrm{H}-1,16-18 \mathrm{~cm}$. 3. Framboidal pyrite filling primary pore spaces within foraminifer ("F") and between sand grains (arrows), 493.71 mbsf, plane light; Sample 141-860B-58X-1, 91-93 cm. 4. Framboidal pyrite replacing layer of fine sand (arrow), $4.39 \mathrm{mbsf}$, plane light; Sample 141-862A-1H-3, 139-141 cm. 5. Burrow lined with quartz grains (arrows indicate diffuse boundary), crosscut by cluster of framboidal pyrite, $181.71 \mathrm{mbsf}$, plane light; Sample 141-861C-22X-2, 31-33 cm. 6-7. Pyrite concretion; $2 \mathrm{~mm}$ long, oval shape in center of (6) in coarse silt and very fine sand. The right side of the concretion is at the left side of (7). The concretion terminates irregularly at the diffuse edge of a vein structure where grain size decreases to clay (arrows), 428.51 mbsf, plane light; Sample 141-860B-50X-3, 21-25 cm. 

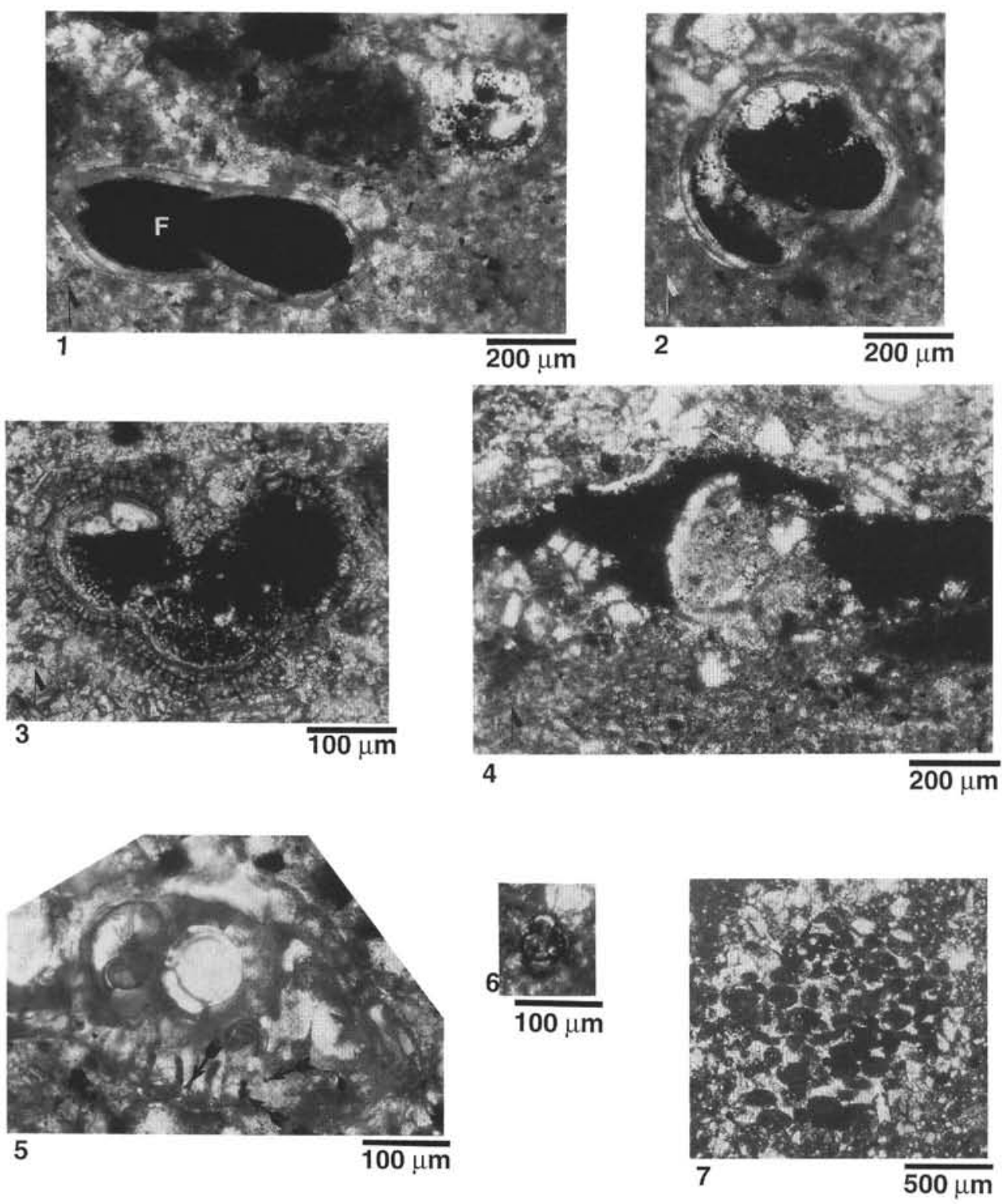

Plate 3. Photomicrographs of pyrite in microfossils. Single-bar arrow indicates direction of stratigraphic tops. 1-2. Microfossils completely ("F") and partially filled (arrows) with pyrite: partial fills are geopetal, $19.91 \mathrm{mbsf}$, plane light; Sample 141-860B-3H-7, 1-6 cm. 3. Geopetal filling of pyrite framboids in foraminifer, $4.68 \mathrm{mbsf}$, plane light with Alizarin Red-S stain for calcite; Sample 141-861 A-1H-4, 18-20 cm. 4. Cluster of pyrite framboids draped over and around a foraminifer, plane light, 142.31 mbsf; Sample 141-860B-19X-4, 71-73 cm. 5. Incipient filling of cavities in calcareous microfossil shell by pyrite framboids (arrows), $142.31 \mathrm{mbsf}$, plane light; Sample 141-860B-19X-4, 71-73 cm. 6. Microfossil completely outlined by pyrite, 493.71 mbsf, plane light; Sample 141-860B-58X-1,91-93 cm. 7 . Ball of fecal pellets with framboidal pyrite replacing some pellets (arrows), 493.71 mbsf, plane light; Sample 141-860B-58X-1, 91-93 cm. 

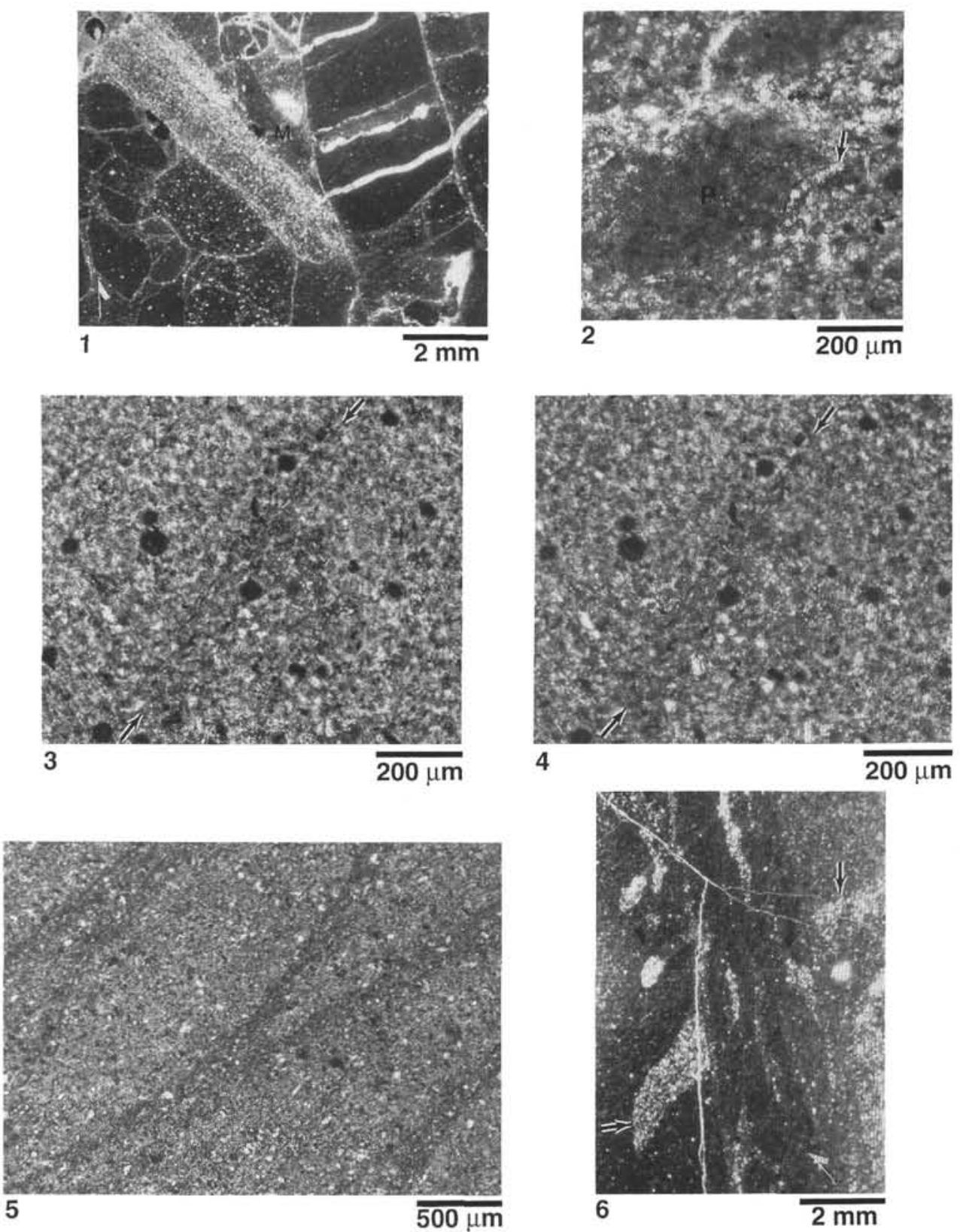

Plate 4. Photomicrographs of structures. 1. Granule conglomerate with fabric of oriented clays in matrix ("M"); fabric is oriented differently in each clast as indicated by different shades of gray and by layering; $299.18 \mathrm{mbsf}$, cross-polarized light with gypsum plate: Sample 141-861C-36X-3,58-60 cm. 2. Fecal pellet ("P") deformed against shell fragment (arrow) during compaction, $181.71 \mathrm{mbsf}$, plane light, calcite stained with Alizarin Red-S; Sample 141-86IC-22X-2,3I-33 cm. 3-4. Vein structure or fault (arrows) in silty clay, $57.96 \mathrm{mbsf}$, Sample 141-863A-7X-2, $36-38 \mathrm{~cm}$. Structure is only slightly darker than host rock in plane light (3), becomes a little more visible in crosspolarized light with gypsum plate because of preferred orientation of clays within the zone (4). 5. Vein structures in silty clay, 488.27 mbsf: preferred orientation of clays within structures is parallel to walls, at a high angle to orientation of clays in surrounding material. Cross-polarized light with gypsum plate, Sample 141-861D-16R-3, 6-10 cm. 6. Multiple vein structures cutting a lens of silt clasts that are the remains of a burrow (arrows). The narrow white lines are cracks in the thin section. 357.11 mbsf, plane light; Sample 141-863B-7N-2, 71-73 cm. 


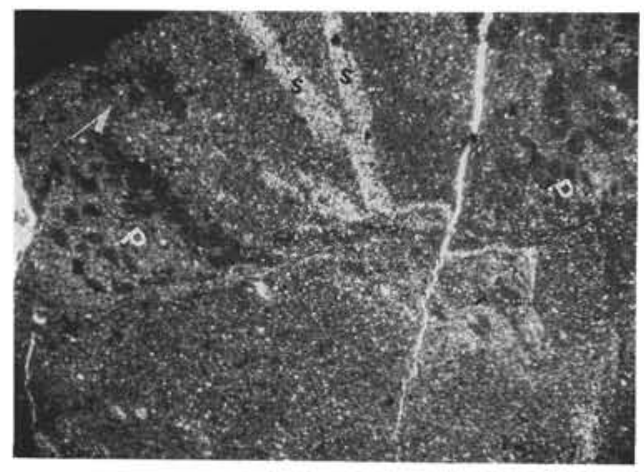

1 $\overline{200 \mu \mathrm{m}}$

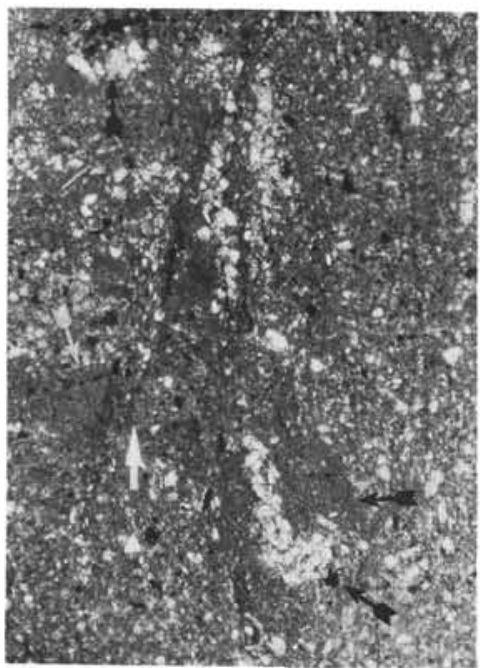

3

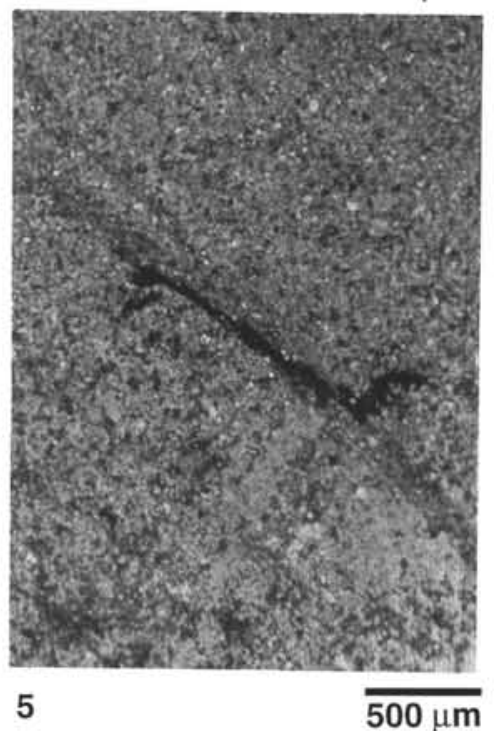

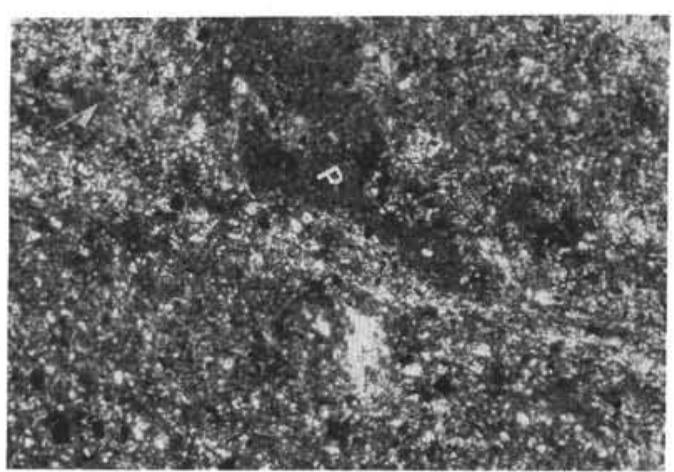

2

$\overline{500 \mu \mathrm{m}}$

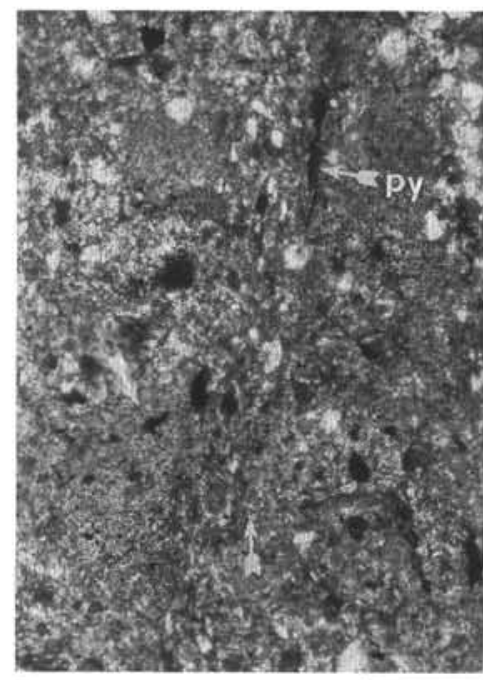

4

$\overline{200 \mu \mathrm{m}}$

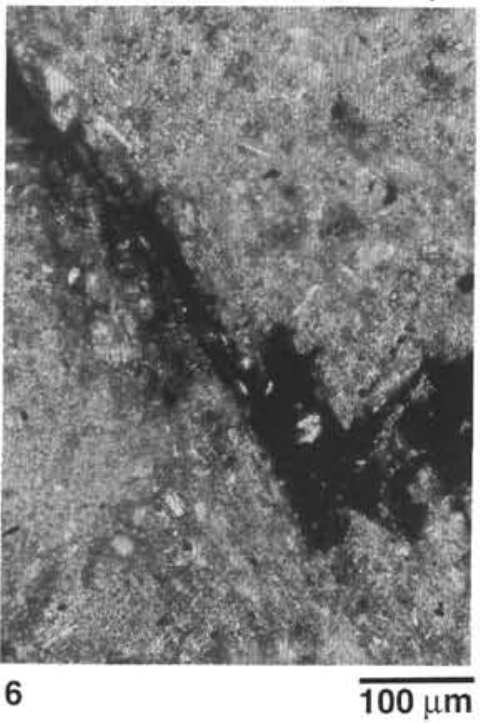

Plate 5. Photomicrographs of faults. 1-2. Faults offsetting layers of silty clay, silt ("S"), and fecal pellets ("P"). The two silt layers in upper center of the view appear to terminate at a fault. (2) is a closeup of a pellet which has been dragged along the fault; view is slightly rotated clockwise relative to (1). The white feature extending diagonally from the upper right to the lower center right is a crack in the thin section. 428.19 mbsf, plane light; Sample 141-860B-50X-2, 139-141 cm. 3-4. Burrow (black arrows) cut by two faults, a fecal pellet (solid white arrow) is offset by one fault. (3) general view, (4) closeup of faulted pellets and stringer of pyrite framboids ("py") in fault zone; $582.42 \mathrm{mbsf}$, plane light; Sample 141-860B-67X-3, 22-24 cm. 5-6. Fault with vein structure along it, 488.27 mbsf. Fault offsets pyrite concretion in "deck-of-cards" style. (5) general view, (6) closeup of offset concretion in which individual shears are visible. Cross-polarized light with gypsum plate; Sample 141-861D-16R-3, 6-10 cm. 